\title{
Congenital disorders: epidemiological methods for answering calls for action
}

\author{
Bernadette Modell ${ }^{1} \cdot$ Matthew W. Darlison ${ }^{1}$ (D) $\cdot$ Helen Malherbe $^{2} \cdot$ Sowmiya Moorthie $^{3} \cdot$ Hannah Blencowe $^{4}$. \\ Ramez Mahaini ${ }^{5} \cdot$ Maha El-Adawy $^{6}$
}

Received: 6 September 2018 / Accepted: 11 September 2018 / Published online: 19 September 2018

(C) Springer-Verlag GmbH Germany, part of Springer Nature 2018

\section{Introduction}

The importance of congenital disorders (also called birth defects) as a cause of early death and disability becomes increasingly apparent as countries pass through the development window and background mortality falls (Malherbe et al. 2015). Consequently, there is growing recognition of the need for their care and prevention, particularly in low- and middle-income countries. In 2010, the World Health Assembly (WHA) expressed concern that birth defects are still not recognised as a priority in public health, and called upon its member states to strengthen the prevention of congenital disorders and provision of care for those affected (World Health Assembly 2010). Nevertheless, the 2015 International Conference on Birth Defects and Disabilities in the Developing World concluded that "as the Sustainable Development Goals are adopted by United Nations member states, children with congenital disorders remain left behind in policies, programs, research, and funding" (Darmstadt et al. 2016).

Matthew W. Darlison

m.darlison@ucl.ac.uk

1 WHO Collaborating Centre for Community Genetics, Centre for Health Informatics and Multiprofessional Education (CHIME), University College London, London, UK

2 School of Clinical Medicine, College of Health Sciences, University of KwaZulu-Natal, Durban, South Africa

3 PHG Foundation, 2 Worts Causeway, Cambridge, UK

4 Maternal Adolescent Reproductive and Child Health Centre, London School of Hygiene and Tropical Medicine, London, UK

5 Maternal and Child Health, WHO Regional Office for the Eastern Mediterranean, Cairo, Egypt

6 Department of Health Protection and Promotion, WHO Regional Office for the Eastern Mediterranean, Cairo, Egypt
In fact, two WHO regional offices (those for the Eastern Mediterranean and South-East Asia) have responded to the call from World Health Assembly. In the process, both have encountered important barriers to the development of health policy in this area. Firstly, policy requires a sound epidemiological base, but in most middle- and low-income countries, the combination of (a) limited resources for the correct and accurate diagnosis of congenital disorders and (b) inadequate information systems leads to gross under-estimation of the contribution of congenital disorders to early death and disability (Christianson et al. 2006; Christianson and Modell 2004; World Health Organization 1999). Secondly, the extreme diversity of congenital disorders makes them difficult to grasp collectively at a strategic public health level. Thirdly, these problems are compounded by failure to agree and implement precise and rigorous technical terminology (World Health Organization 2006). The database described in the following articles - the Modell Global Database of Congenital Disorders (MGDb) - has been developed in order to overcome these barriers to service development.

\section{Congenital disorders}

The World Health Organization defined congenital disorders as "any potential pathological conditions arising before birth, whether evident at birth or manifesting later in life" (World Health Organization 2000, 2005, 2006). Using this definition, congenital disorders fall into two main groups: environmental congenital disorders due to maternal exposure to infection, malnutrition, or harmful environmental agents (Wittenburg 2009) and congenital disorders with principally endogenous causes. This second group, here collectively called constitutional congenital disorders, includes chromosomal disorders, the majority of congenital malformations, single gene disorders, and disorders due to genetic risk factors. 
In 2006, the March of Dimes published provisional estimates of the global birth prevalence of congenital disorders (Christianson et al. 2006). The report was endorsed by the World Health Organization (2006) and led to the World Health Assembly Resolution on Birth Defects (World Health Assembly 2010). This noted the lack of sound estimates of the number of children born with a serious congenital disorder, and recommended (a) collection of data on the global burden of mortality and morbidity due to birth defects and (b) resolution of divergent opinions on their health burden.

While the specialist literature contains a wealth of high quality information on prevalence and outcomes of congenital disorders, neither the data nor its collective implications have been effectively communicated to the global or national public health communities. In addition, though the experience in high-income countries shows that around $70 \%$ of congenital disorders can be prevented or successfully treated (Alwan and Modell 2003; Czeizel et al. 1993; World Health Organization 1996), this requires a range of interventions - treatments and preventive measures - that were introduced piecemeal as they evolved, but which have never been recognised as forming a single coherent package of care. The MGDb aims to overcome these difficulties by harnessing whatever data there is to generate evidence-based epidemiological estimates for congenital disorders. Recognising that public health policy-makers and primary care services prefer to deal with packages of care appropriate for delivery at different life stages rather than with single issues, it is helpful to group interventions with known effects into a portfolio of options that policy-makers can consider for integration into compartments of health services.

The primary focus of past international policy recommendations has been on preventing environmental congenital disorders, because public health initiatives including immunisation, micronutrient supplementation, avoidance of harmful exposures, and appropriate pregnancy care can reduce their prevalence by $90 \%$ or more. We estimate that as a result their global birth prevalence has fallen by approximately $50 \%$ so that they now make up around $15 \%$ of total congenital disorders. In contrast, the far larger group of constitutional disorders has been relatively neglected in public health policy-making, though their importance emerges as other causes of early mortality and disability are brought under control and countries transition epidemiologically. The main challenge that remains is that of developing effective policies for prevention and care of this large and diverse disorder group.

\section{Assembling a global epidemiological evidence base}

In response, an international expert group came together to identify, assemble, interpret, and triangulate epidemiological information from a wide range of sources and to relate it to global demographic data in order to estimate the birth prevalences and outcomes of constitutional congenital disorders at the country, WHO region, and global levels, and express the results in the scientific language of public health. Products of this process included the prototype MGDb implementation and the associated methods (the focus of this special issue), and the publication online of the first selected country-specific data (Table Annexes published as part of Modell et al. 2016) with related resources collected on a dedicated website. ${ }^{1}$

The aims of the MGDb are (a) to provide order of magnitude estimates for every country, which can be used to support policy-making when available observational data is inadequate, and (b) to encourage local public health officials, policy-makers, their expert advisors, and non-governmental advocates to participate by generating their own estimates for comparison with available local observational data. Accordingly, the database was developed with the following guiding principles.

- The methods used must be as simple and reproducible as possible.

- It should use collective data sources that are as robust and as authoritative as possible, ideally freely available online-i.e. it should build on comprehensive datasets assembled and routinely published by others. ${ }^{2}$

- Methods must be shared in full detail (Modell et al. 2016).

- Despite their variety, congenital disorders must be aggregated into manageable groups, and outcomes must be described in terms relevant to public health, such as effect of interventions on early mortality, disability, and service need.

- All estimates must be made for every country, even (especially) when no observational data are available. In such cases, an estimate must be used that is as evidencebased as reasonably possible. ${ }^{3}$

- Since estimates are offered for use in policy development, the priority is to avoid over-estimation. All estimates should be the lowest compatible with available data.

Current MGDb estimates indicate that at present, worldwide, annually, over 5 million births are affected with a congenital disorder, resulting in over 400,000 fetal deaths, 2.5 million under-5 deaths, and 2 million survivors with

\footnotetext{
$\overline{1}$ http://mgdb.info

${ }^{2}$ Examples include United Nations World Population Prospects (WPP) demographic data, EUROCAT and ICBDSR umbrella congenital anomaly registries, Livingstone's database of haemoglobin disorders and G6PD deficiency (Livingstone 1985), Murdock's ethnographic atlas (Murdock 1967), Bittles' consanguinity database at consang.net, Institute for Health Metrics and Evaluation (IHME) global burden of disease (GBD) study outputs, and key published articles, e.g. Tennant et al. (2010) mortality estimates.

${ }^{3}$ Note the great nuclear physicist Fermi's famous recommendations: not to devote more time and effort to a problem than it is worth, and not to make something more accurate than absolutely necessary.
} 
significant disability at 5 years. ${ }^{4}$ Hitherto, the primary emphasis in reviewing adverse outcomes of congenital disorders has been on reducing mortality. The prevention of and care for the disability that results require at least equivalent attention, since with increasing access to more effective care comes a steady rise in numbers surviving with disability and a greater need for disability services worldwide.

MGDb estimates also confirm that full deployment of available interventions could both reduce the birth prevalence of environmental congenital disorders to a very low level and reduce adverse outcomes of constitutional congenital disorders by $50-80 \%$.

\section{The need for agreed terminology}

Ostensibly, there are wide differences between current estimates of mortality and disability due to congenital disorders produced by the Global Burden of Disease study (GBD) and WHO on the one hand, and the March of Dimes and MGDb on the other (Liu et al. 2012a, b; Lozano et al. 2012; Modell et al. 2012). However, a considerable part of the difference reflects a lack of agreed technical terminology for reporting. For example, GBD makes estimates for congenital anomalies as defined in Chapter XVII ("the Q chapter") of the International Classification of Diseases: "congenital malformations, deformations and chromosomal abnormalities" (Vos et al. 2017; World Health Organization 1992), but this covers only the sub-set of congenital disorders associated with anatomical abnormality. However, the term congenital anomalies is often used loosely to represent all congenital disorders, and as a result, the GBD estimates are easily misinterpreted, with the profound consequence that the burden of congenital disorders is grossly under-estimated. For this reason, the first recommendation of the 2015 International Conference on Birth Defects and Disabilities in the Developing World was "to build consensus on a standardized definition of congenital disorders and promote its widespread use" (Darmstadt et al. 2016). The proposed definition"abnormalities of structure or function which are present from birth" - corresponds closely with the WHO definition used in the MGDb (World Health Organization 2006).

In the course of building the database, we encountered many other examples showing the need for technical scientific consensus on the terminology for congenital disorders: in order to proceed, we created and shared a set of provisional working definitions for consultation (Modell et al. 2016).

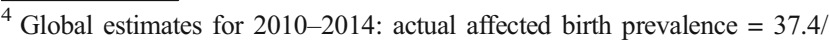
1000 , leading to $3 / 1000$ fetal deaths, $17.9 / 1000$ under-5 deaths, and $15 / 1000$ survivors with disability at 5 years.
}

\section{WHO regional initiatives}

The WHO Eastern Mediterranean Region (EMR) has a particularly high prevalence of congenital disorders, partly related to the local high prevalence of parental consanguinity (Alwan et al. 1997). Many of the disorders that are commonly diagnosed in the region are preventable using low-cost, high-impact interventions such as food fortification and immunisation. Paediatric surgery has been recognised as a priority intervention for preventing newborn and infant deaths due to congenital malformations and gaining years of life cured or without disability. Screening for genetic reproductive risk, genetic counselling, and prenatal diagnosis with the option of termination of pregnancy, implemented in some countries of the region, has significantly reduced the birth prevalence of thalassaemia and may affect other single gene disorders similarly in the future. Meanwhile, it has become clear that interventions that reduce mortality due to congenital disorders lead to a cumulative increase in numbers surviving with life-long disability and needing access to appropriate health services. However, these interventions are not available to all families in the region. Some are costly, and many couples may not be aware of their existence. Hence, universal coverage is one of the main challenges for services aiming to reduce the burden of congenital disorders for families and the population as a whole. Responding to this situation, the WHO Regional Office for the Eastern Mediterranean (EMRO) has (a) supported the development of the MGDb in order to obtain independently-generated benchmark epidemiological estimates for EMR countries and (b) embarked on a maternal and child health-led programme aiming to strengthen pre-conception care through high-impact, cost-effective, and evidence-based interventions, and to support the efforts of Member States to address the burden of congenital disorders (World Health Organization 2015).

Similarly, the WHO Regional Office for South-East Asia (SEARO) is actively developing and implementing a regional strategic framework for prevention and control of birth defects (World Health Organization 2013).

\section{Wider use of the methods}

This special issue shows that the methods used in the MGDb to generate estimates of the birth prevalence and outcomes of congenital disorders are simple and reliable enough to be used within any Ministry of Health, as well as by groups advocating appropriate service development. An important limitation is that MGDb estimates apply only for whole countries: this is often inadequate, particularly for large, diverse countries such as Brazil, China, India, or South Africa. Application of MGDb methods to generate within-country estimates has been piloted in South Africa, resulting in a local epidemiological database, the MGDb-ZA, which applies the methods to locally sourced 
demographic data to generate estimates of the burden of congenital disorders at sub-national civil divisions (provinces in South Africa). Typically for a middle-income country, South Africa lacks empirical data for congenital disorders (Lebese et al. 2016): the MGDb-ZA now offers a tool to leverage increased political commitment to prioritise congenital disorders as a health care issue and develop the necessary services for care and prevention (Malherbe et al. 2015). A significant part of the work in establishing MDGb-ZA lay in identifying the most relevant and robust data sources in-country, a process that in itself led to the development of key partnerships and collaborations, and attracted the interest of policy-makers even before the initial estimates were available.

\section{Content of this special issue}

The first, historical article in this series shows that efforts to understand the global burden of congenital disorders have been underway for many years, and describes the step-wise evolution of the MGDb, starting from a WHO request for epidemiological information on haemoglobin disorders and progressing gradually towards comprehensive coverage of severe, early-onset congenital disorders.

The second article summarises the general approach used, reviews its strengths and limitations, and presents selected outputs by WHO region and globally. In particular, it shows that the baseline birth prevalence (in the absence of any intervention) of constitutional congenital disorders is relatively constant in any given population, and the only possible outcomes are fetal death, early mortality, disability, or cure. This unique characteristic confers exceptional advantages from an epidemiological point of view, because baseline birth prevalence both provides a solid starting point for quantitative assessment of the effects of interventions and constitutes an envelope that must be filled by the sum of outcomes. That is, these disorder groups can be handled as closed systems.

The third article describes key interventions that are incorporated into the MGDb. Importantly, it also describes the derivation of an equation based on infant mortality rate that can be used to estimate the proportion of a population with access to these interventions, and so to estimate the potential and actual current effects of their deployment on early mortality and disability.

Subsequent articles describe methods that can be used to estimate the prevalence and outcomes of the main groups of constitutional congenital disorders plus summaries of the history, aims, and current status of the two "umbrella" congenital anomaly registries - ICBDSR and EUROCAT - that provide the basis for global estimates for congenital malformations and chromosomal disorders. More detailed descriptions of MGDb methods and additional articles on haemoglobin disorders, rhesus negativity, and G6PD deficiency are available online (Modell et al. 2016).

\section{Conclusion}

The articles in this special issue show that the MGDb estimates of the birth prevalence and outcomes of congenital disorders have a strong evidence base and should be taken into consideration by health policy-makers worldwide.

At the international level, they should encourage authorities including the WHO and the Global Burden of Disease study to raise congenital disorders in the ranking of global health priorities. At the country level, they can contribute to the appropriate development of programmes for prevention and care of congenital disorders. For example, the WHO Regional Office for South-East Asia recommends that each Ministry of Health designate a national focal point within the ministry and establish a national technical working group to develop a national strategic plan for prevention and control of congenital disorders (World Health Organization 2013). The MGDb estimates contribute significantly to the obvious first task of such a national working group, namely to review available data on the local causes, birth prevalence, and outcomes of congenital disorders, and assess appropriate available interventions, their costs, and their benefits.

\section{References}

Alwan A, Modell B (2003) Recommendations for introducing genetics services in developing countries. Nat Rev Genet 4:61-68. https:// doi.org/10.1038/nrg978

Alwan Ad, Modell B, Bittles A, Czeizel A, Hamamy H (1997) Community control of genetic and congenital disorders. WHO EMRO technical publication, vol no 24. WHO Regional Office for the Eastern Mediterranean, Alexandria

Christianson A, Modell B (2004) Medical genetics in developing countries. Annu Rev Genomics Hum Genet 5:219-265. https://doi.org/ 10.1146/annurev.genom.5.061903.175935

Christianson A, Howson C, Modell B (2006) March of Dimes: Global Report on Birth Defects, the Hidden Toll of Dying and Disabled Children. March of Dimes Birth Defects Foundation, New York

Czeizel A, Intôdy Z, Modell B (1993) What proportion of congenital abnormalities can be prevented? Bmj 306:499-503. https://doi.org/ 10.1136/bmj.306.6876.499

Darmstadt GL, Howson CP, Walraven G, Armstrong RW, Blencowe HK, Christianson AL, Kent A, Malherbe H, Murray JC, Padilla CD, Walani SR, for the Participant Working Group of the Dar es Salaam Seventh International Conference on Birth Defects and Disabilities in the Developing World (2016) Prevention of congenital disorders and care of affected children: a consensus statement. JAMA Pediatr 170:790-793. https://doi.org/10.1001/ jamapediatrics.2016.0388

Lebese L, Aldous C, Malherbe H (2016) South African congenital disorders data, 2006 - 2014. S Afr Med J 106:992-995. https://doi.org/ 10.7196/samj.2016.v106i10.11314 
Liu L, Cousens S, Lawn JE, Black RE (2012a) Global regional and national causes of child mortality-authors' reply. Lancet 380: $1556-1557$

Liu L, Johnson HL, Cousens S, Perin J, Scott S, Lawn JE, Rudan I, Campbell H, Cibulskis R, Li M, Mathers C, Black RE (2012b) Global, regional, and national causes of child mortality: an updated systematic analysis for 2010 with time trends since 2000. Lancet 379:2151-2161. https://doi.org/10.1016/S0140-6736(12)60560-1

Livingstone FB (1985) Frequencies of hemoglobin variants : thalassemia, the glucose-6-phosphate dehydrogenase deficiency, G6PD variants, and ovalocytosis in human populations. Oxford University Press, New York

Lozano R, Naghavi M, Foreman K, Lim S, Shibuya K, Aboyans V, Abraham J, Adair T, Aggarwal R, Ahn SY, AlMazroa MA, Alvarado $\mathrm{M}$, Anderson HR, Anderson LM, Andrews KG, Atkinson C, Baddour LM, Barker-Collo S, Bartels DH, Bell ML, Benjamin EJ, Bennett D, Bhalla K, Bikbov B, Abdulhak AB, Birbeck G, Blyth F, Bolliger I, Boufous S, Bucello C, Burch M, Burney P, Carapetis J, Chen H, Chou D, Chugh SS, Coffeng LE, Colan SD, Colquhoun S, Colson KE, Condon J, Connor MD, Cooper LT, Corriere M, Cortinovis M, de Vaccaro KC, Couser W, Cowie BC, Criqui MH, Cross M, Dabhadkar KC, Dahodwala N, de Leo D, Degenhardt L, Delossantos A, Denenberg J, Des Jarlais DC, Dharmaratne SD, Dorsey ER, Driscoll T, Duber H, Ebel B, Erwin PJ, Espindola P, Ezzati M, Feigin V, Flaxman AD, Forouzanfar MH, Fowkes FGR, Franklin R, Fransen M, Freeman MK, Gabriel SE, Gakidou E, Gaspari F, Gillum RF, Gonzalez-Medina D, Halasa YA, Haring D, Harrison JE, Havmoeller R, Hay RJ, Hoen B, Hotez PJ, Hoy D, Jacobsen KH, James SL, Jasrasaria R, Jayaraman S, Johns N, Karthikeyan G, Kassebaum N, Keren A, Khoo JP, Knowlton LM, Kobusingye O, Koranteng A, Krishnamurthi R, Lipnick M, Lipshultz SE, Ohno SL, Mabweijano J, MacIntyre MF, Mallinger L, March L, Marks GB, Marks R, Matsumori A, Matzopoulos R, Mayosi BM, McAnulty JH, McDermott MM, McGrath J, Memish ZA, Mensah GA, Merriman TR, Michaud C, Miller M, Miller TR, Mock C, Mocumbi AO, Mokdad AA, Moran A, Mulholland K, Nair MN, Naldi L, Narayan KMV, Nasseri K, Norman P, O’Donnell M, Omer SB, Ortblad K, Osborne R, Ozgediz D, Pahari B, Pandian JD, Rivero AP, Padilla RP, Perez-Ruiz F, Perico N, Phillips D, Pierce K, Pope CA III, Porrini E, Pourmalek F, Raju M, Ranganathan D, Rehm JT, Rein DB, Remuzzi G, Rivara FP, Roberts T, de León FR, Rosenfeld LC, Rushton L, Sacco RL, Salomon JA, Sampson U, Sanman E, Schwebel DC, Segui-Gomez M, Shepard DS, Singh D, Singleton J, Sliwa K, Smith E, Steer A, Taylor JA, Thomas B, Tleyjeh IM, Towbin JA, Truelsen T, Undurraga EA, Venketasubramanian N, Vijayakumar L, Vos T, Wagner GR, Wang M, Wang W, Watt K, Weinstock MA, Weintraub R, Wilkinson JD, Woolf AD, Wulf S, Yeh PH, Yip P, Zabetian A, Zheng ZJ, Lopez AD, Murray CJL (2012) Global and regional mortality from 235 causes of death for 20 age groups in 1990 and 2010: a systematic analysis for the global burden of disease study 2010. Lancet 380:2095-2128. https://doi.org/10.1016/ S0140-6736(12)61728-0

Malherbe H, Christianson A, Aldous C (2015) Need for services for the care and prevention of congenital disorders in South Africa as the country's epidemiological transition evolves. S Afr Med J 105:186188. https://doi.org/10.7196/samj.9136

Modell B, Berry RJ, Boyle CA, Christianson A, Darlison M, Dolk H, Howson CP, Mastroiacovo P, Mossey P, Rankin J (2012) Global regional and national causes of child mortality. Lancet 380:1556; author reply 1556-1557. https://doi.org/10.1016/S0140-6736(12) 61878-9

Modell B, Darlison MW, Moorthie S, Blencowe H, Petrou M, Lawn J (2016) Epidemiological Methods in Community Genetics and the Modell Global Database of Congenital Disorders (MGDb). http:// discovery.ucl.ac.uk/1532179/
Murdock GP (1967) Ethnographic atlas. Univ. of Pittsburgh, [S.1.]

Tennant PW, Pearce MS, Bythell M, Rankin J (2010) 20-year survival of children born with congenital anomalies: a population-based study. Lancet 375:649-656. https://doi.org/10.1016/S0140-6736(09) 61922-X

Vos T, Abajobir AA, Abate KH, Abbafati C, Abbas KM, Abd-Allah F, Abdulkader RS, Abdulle AM, Abebo TA, Abera SF, Aboyans V, Abu-Raddad LJ, Ackerman IN, Adamu AA, Adetokunboh O, Afarideh M, Afshin A, Agarwal SK, Aggarwal R, Agrawal A, Agrawal S, Ahmadieh H, Ahmed MB, Aichour MTE, Aichour AN, Aichour I, Aiyar S, Akinyemi RO, Akseer N, al Lami FH, Alahdab F, al-Aly Z, Alam K, Alam N, Alam T, Alasfoor D, Alene KA, Ali R, Alizadeh-Navaei R, Alkerwi A, Alla F, Allebeck P, Allen C, al-Maskari F, al-Raddadi R, Alsharif U, Alsowaidi S, Altirkawi KA, Amare AT, Amini E, Ammar W, Amoako YA, Andersen HH, Antonio CAT, Anwari P, Ärnlöv J, Artaman A, Aryal KK, Asayesh H, Asgedom SW, Assadi R, Atey TM, Atnafu NT, Atre SR, Avila-Burgos L, Avokphako EFGA, Awasthi A, Bacha U, Badawi A, Balakrishnan K, Banerjee A, Bannick MS, Barac A, Barber RM, Barker-Collo SL, Bärnighausen T, Barquera S, Barregard L, Barrero LH, Basu S, Battista B, Battle KE, Baune BT, Bazargan-Hejazi S, Beardsley J, Bedi N, Beghi E, Béjot Y, Bekele BB, Bell ML, Bennett DA, Bensenor IM, Benson J, Berhane A, Berhe DF, Bernabé E, Betsu BD, Beuran M, Beyene AS, Bhala N, Bhansali A, Bhatt S, Bhutta ZA, Biadgilign S, Bicer BK, Bienhoff K, Bikbov B, Birungi C, Biryukov S, Bisanzio D, Bizuayehu HM, Boneya DJ, Boufous S, Bourne RRA, Brazinova A, Brugha TS, Buchbinder R, Bulto LNB, Bumgarner BR, Butt ZA, Cahuana-Hurtado L, Cameron E, Car M, Carabin H, Carapetis JR, Cárdenas R, Carpenter DO, Carrero JJ, Carter A, Carvalho F, Casey DC, Caso V, Castañeda-Orjuela CA, Castle CD, Catalá-López F, Chang HY, Chang JC, Charlson FJ, Chen H, Chibalabala M, Chibueze CE, Chisumpa VH, Chitheer AA, Christopher DJ, Ciobanu LG, Cirillo M, Colombara D, Cooper C, Cortesi PA, Criqui MH, Crump JA, Dadi AF, Dalal K, Dandona L, Dandona R, das Neves J, Davitoiu DV, de Courten B, de Leo DD, Defo BK, Degenhardt L, Deiparine S, Dellavalle RP, Deribe K, Des Jarlais DC, Dey S, Dharmaratne SD, Dhillon PK, Dicker D, Ding EL, Djalalinia S, Do HP, Dorsey ER, dos Santos KPB, Douwes-Schultz D, Doyle KE, Driscoll TR, Dubey M, Duncan BB, el-Khatib ZZ, Ellerstrand J, Enayati A, Endries AY, Ermakov SP, Erskine HE, Eshrati B, Eskandarieh S, Esteghamati A, Estep K, Fanuel FBB, Farinha CSES, Faro A, Farzadfar F, Fazeli MS, Feigin VL, Fereshtehnejad SM, Fernandes JC, Ferrari AJ, Feyissa TR, Filip I, Fischer F, Fitzmaurice C, Flaxman AD, Flor LS, Foigt N, Foreman KJ, Franklin RC, Fullman N, Fürst T, Furtado JM, Futran ND, Gakidou E, Ganji M, Garcia-Basteiro AL, Gebre T, Gebrehiwot TT, Geleto A, Gemechu BL, Gesesew HA, Gething PW, Ghajar A, Gibney KB, Gill PS, Gillum RF, Ginawi IAM, Giref AZ, Gishu MD, Giussani G, Godwin WW, Gold AL, Goldberg EM, Gona PN, Goodridge A, Gopalani SV, Goto A, Goulart AC, Griswold M, Gugnani HC, Gupta R, Gupta R, Gupta T, Gupta V, Hafezi-Nejad N, Hailu GB, Hailu AD, Hamadeh RR, Hamidi S, Handal AJ, Hankey GJ, Hanson SW, Hao Y, Harb HL, Hareri HA, Haro JM, Harvey J, Hassanvand MS, Havmoeller R, Hawley C, Hay SI, Hay RJ, Henry NJ, Heredia-Pi IB, Hernandez JM, Heydarpour P, Hoek HW, Hoffman HJ, Horita N, Hosgood HD, Hostiuc S, Hotez PJ, Hoy DG, Htet AS, $\mathrm{Hu} \mathrm{G}$, Huang H, Huynh C, Iburg KM, Igumbor EU, Ikeda C, Irvine CMS, Jacobsen KH, Jahanmehr N, Jakovljevic MB, Jassal SK, Javanbakht M, Jayaraman SP, Jeemon P, Jensen PN, Jha V, Jiang G, John D, Johnson SC, Johnson CO, Jonas JB, Jürisson M, Kabir Z, Kadel R, Kahsay A, Kamal R, Kan H, Karam NE, Karch A, Karema CK, Kasaeian A, Kassa GM, Kassaw NA, Kassebaum NJ, Kastor A, Katikireddi SV, Kaul A, Kawakami N, Keiyoro PN, Kengne AP, Keren A, Khader YS, Khalil IA, Khan EA, Khang YH, 
Khosravi A, Khubchandani J, Kiadaliri AA, Kieling C, Kim YJ, Kim D, Kim P, Kimokoti RW, Kinfu Y, Kisa A, KissimovaSkarbek KA, Kivimaki M, Knudsen AK, Kokubo Y, Kolte D, Kopec JA, Kosen S, Koul PA, Koyanagi A, Kravchenko M, Krishnaswami S, Krohn KJ, Kumar GA, Kumar P, Kumar S, Kyu HH, Lal DK, Lalloo R, Lambert N, Lan Q, Larsson A, Lavados PM, Leasher JL, Lee PH, Lee JT, Leigh J, Leshargie CT, Leung J, Leung R, Levi M, Li Y, Li Y, Li Kappe D, Liang X, Liben ML, Lim SS, Linn S, Liu PY, Liu A, Liu S, Liu Y, Lodha R, Logroscino G, London SJ, Looker KJ, Lopez AD, Lorkowski S, Lotufo PA, Low N, Lozano R, Lucas TCD, Macarayan ERK, Magdy Abd el Razek H, Magdy Abd el Razek M, Mahdavi M, Majdan M, Majdzadeh R, Majeed A, Malekzadeh R, Malhotra R, Malta DC, Mamun AA, Manguerra H, Manhertz T, Mantilla A, Mantovani LG, Mapoma CC, Marczak LB, Martinez-Raga J, Martins-Melo FR, Martopullo I, März W, Mathur MR, Mazidi M, McAlinden C, McGaughey M, McGrath JJ, McKee M, McNellan C, Mehata S, Mehndiratta MM, Mekonnen TC, Memiah P, Memish ZA, Mendoza W, Mengistie MA, Mengistu DT, Mensah GA, Meretoja TJ, Meretoja A, Mezgebe HB, Micha R, Millear A, Miller TR, Mills EJ, Mirarefin M, Mirrakhimov EM, Misganaw A, Mishra SR, Mitchell PB, Mohammad KA, Mohammadi A, Mohammed KE, Mohammed S, Mohanty SK, Mokdad AH, Mollenkopf SK, Monasta L, Montico M, Moradi-Lakeh M, Moraga P, Mori R, Morozoff C, Morrison SD, Moses M, Mountjoy-Venning C, Mruts KB, Mueller UO, Muller K, Murdoch ME, Murthy GVS, Musa KI, Nachega JB, Nagel G, Naghavi M, Naheed A, Naidoo KS, Naldi L, Nangia V, Natarajan G, Negasa DE, Negoi RI, Negoi I, Newton CR, Ngunjiri JW, Nguyen TH, Nguyen QL, Nguyen CT, Nguyen G, Nguyen M, Nichols E, Ningrum DNA, Nolte S, Nong VM, Norrving B, Noubiap JJN, O'Donnell MJ, Ogbo FA, Oh IH, Okoro A, Oladimeji O, Olagunju TO, Olagunju AT, Olsen HE, Olusanya BO, Olusanya JO, Ong K, Opio JN, Oren E, Ortiz A, OsgoodZimmerman A, Osman M, Owolabi MO, PA M, Pacella RE, Pana A, Panda BK, Papachristou C, Park EK, Parry CD, Parsaeian M, Patten SB, Patton GC, Paulson K, Pearce N, Pereira DM, Perico N, Pesudovs K, Peterson CB, Petzold M, Phillips MR, Pigott DM, Pillay JD, Pinho C, Plass D, Pletcher MA, Popova S, Poulton RG, Pourmalek F, Prabhakaran D, Prasad NM, Prasad N, Purcell C, Qorbani M, Quansah R, Quintanilla BPA, Rabiee RHS, Radfar A, Rafay A, Rahimi K, Rahimi-Movaghar A, Rahimi-Movaghar V, Rahman MHU, Rahman M, Rai RK, Rajsic S, Ram U, Ranabhat CL, Rankin Z, Rao PC, Rao PV, Rawaf S, Ray SE, Reiner RC, Reinig N, Reitsma MB, Remuzzi G, Renzaho AMN, Resnikoff S, Rezaei S, Ribeiro AL, Ronfani L, Roshandel G, Roth GA, Roy A, Rubagotti E, Ruhago GM, Saadat S, Sadat N, Safdarian M, Safi S, Safiri S, Sagar R, Sahathevan R, Salama J, Saleem HOB, Salomon JA, Salvi SS, Samy AM, Sanabria JR, Santomauro D, Santos IS, Santos JV, Santric Milicevic MM, Sartorius B, Satpathy M, Sawhney M, Saxena S, Schmidt MI, Schneider IJC, Schöttker B, Schwebel DC, Schwendicke F, Seedat S, Sepanlou SG, ServanMori EE, Setegn T, Shackelford KA, Shaheen A, Shaikh MA, Shamsipour M, Shariful Islam SM, Sharma J, Sharma R, She J, Shi P, Shields C, Shifa GT, Shigematsu M, Shinohara Y, Shiri R, Shirkoohi R, Shirude S, Shishani K, Shrime MG, Sibai AM, Sigfusdottir ID, Silva DAS, Silva JP, Silveira DGA, Singh JA, Singh NP, Sinha DN, Skiadaresi E, Skirbekk V, Slepak EL, Sligar A, Smith DL, Smith M, Sobaih BHA, Sobngwi E, Sorensen RJD, Sousa TCM, Sposato LA, Sreeramareddy CT, Srinivasan V,
Stanaway JD, Stathopoulou V, Steel N, Stein MB, Stein DJ, Steiner TJ, Steiner C, Steinke S, Stokes MA, Stovner LJ, Strub B, Subart M, Sufiyan MB, Sunguya BF, Sur PJ, Swaminathan S, Sykes BL, Sylte DO, Tabarés-Seisdedos R, Taffere GR, Takala JS, Tandon N, Tavakkoli M, Taveira N, Taylor HR, Tehrani-Banihashemi A, Tekelab T, Terkawi AS, Tesfaye DJ, Tesssema B, Thamsuwan O, Thomas KE, Thrift AG, Tiruye TY, Tobe-Gai R, Tollanes MC, Tonelli M, Topor-Madry R, Tortajada M, Touvier M, Tran BX, Tripathi S, Troeger C, Truelsen T, Tsoi D, Tuem KB, Tuzcu EM, Tyrovolas S, Ukwaja KN, Undurraga EA, Uneke CJ, Updike R, Uthman OA, Uzochukwu BSC, van Boven JFM, Varughese S, Vasankari T, Venkatesh S, Venketasubramanian N, Vidavalur R, Violante FS, Vladimirov SK, Vlassov VV, Vollset SE, Wadilo F, Wakayo T, Wang YP, Weaver M, Weichenthal S, Weiderpass E, Weintraub RG, Werdecker A, Westerman R, Whiteford HA, Wijeratne T, Wiysonge CS, Wolfe CDA, Woodbrook R, Woolf AD, Workicho A, Xavier D, Xu G, Yadgir S, Yaghoubi M, Yakob B, Yan LL, Yano Y, Ye P, Yimam HH, Yip P, Yonemoto N, Yoon SJ, Yotebieng M, Younis MZ, Zaidi Z, Zaki MES, Zegeye EA, Zenebe ZM, Zhang X, Zhou M, Zipkin B, Zodpey S, Zuhlke LJ, Murray CJL (2017) Global, regional, and national incidence, prevalence, and years lived with disability for 328 diseases and injuries for 195 countries, 1990-2016: a systematic analysis for the Global Burden of Disease Study 2016. Lancet 390:1211-1259. https://doi. org/10.1016/S0140-6736(17)32154-2

Wittenburg D (2009) Coovadia's paediatrics and child health: a manual for health professionals in developing countries, 6th edn. Oxford University Press Southern Africa, Cape Town

World Health Assembly (2010) Sixty-Third World Health Assembly Resolution 63.17. Birth Defects vol 2014. World Health Organization

World Health Organization (1992) International Statistical Classification of Diseases and Related Health Problems. 10th revision. World Health Organization, Geneva

World Health Organization (1996) Control of hereditary diseases: report of a WHO scientific group 1993, Geneva, Switzerland. World Health Organization, Geneva

World Health Organization (1999) Services for the Prevention and Management of Genetic Disorders and Birth Defects in Developing Countries. Report of a Joint WHO/WAOPBD Meeting, The Hague, 5-7 January 1999. World Health Organization, Geneva

World Health Organization (2000) Primary health care approaches for prevention and control of congenital and genetic disorders : report of a WHO meeting, Cairo, Egypt, 6-8 December 1999. World Health Organization, Geneva

World Health Organization (2005) Community approaches to the control of hereditary diseases. Report of a WHO Advisory Group, Geneva, 3-5 October 1985. World Health Organization, Geneva

World Health Organization (2006) Management of Birth Defects and Haemoglobin Disorders. Report of a Joint who-March of Dimes Meeting. Geneva, Switzerland, 17-19 May 2006. World Health Organization, Geneva

World Health Organization (2015) Summary report on the Meeting on promoting preconception care in the Eastern Mediterranean Region, Muscat, Oman 25-27 March 2015

World Health Organization ROfS-EA (2013) Prevention and control of birth defects in South-East Asia Region: strategic framework (2013-2017) 